\title{
TINJAUAN YURIDIS TERHADAP WANPRESTASI DALAM PERJANJIAN KREDIT ANTARA BANK BPR DENGAN NASABAH (Studi di Perumda BPR Majalengka).
}

\author{
Lela Sri Nulaela ${ }^{1}$ \\ Email :lelasrinurlaela27@gmail.com
}

\begin{abstract}
ABSTRAK
Dewasa ini pembangunan ekonomi di Indonesia terletak pada sektor perbankan,dalammelakukankegiatansehari-hari masyarakat sangat membutuhkan bank dalam melakukankegiatantransaksikeuangan, dengan adanya fasilitas Kredit yang tersedia pada Perumda BPR Majalengka, memberikan kesempatan kepada masyarakat untuk mengajukan kredit di Perumda BPR Majalengka. Dalam pratek Perjanjian Kredit Perumda BPR Majalengka menggunakan prinsip kehati-hatian berdasarkan asas kredit yang sehat dan setiap kredit yang diberikan ada jaminannya.

Berdasarkan latar belakang tersebut, identifikasi masalah yang penulis ambil antara lain, bagaimana pelaksanaan Perjanjian Kredit antara Perumda BPR Majalengka dengan debitur dan bagaimana akibat hukum yang dilakukan apabila terjadi Wanprestasi.

Metode penelitian yang digunakan yaitu teknik wawancara dengan pihak-pihak terkait dalam Perjanjian Kredit, dengan menggunakan metode yuridis-normatif, yaitu penelitian hukum normatif merupakan penelitian yang mengutamakan data kepustakaan yakni data sekunder.

Dalam pelaksanaan perjanjian Kredit antara Perumda BPR Majalengka dengan Debitur. Perjanjian Kredit harus dibuat dengan akta otentik dalam bentuk perjanjian baku yaitu suatu Perjanjian yang sebelumnya telah dipersiapkan dan ditetapkan isi atau klausulklausulnya oleh pihak Perumda BPR Majalengka dalam suatu surat Perjanjian Kredit yang demikian pada hakekatnya kehendak yang sebenarnya belum terwujud dalam Perjanjian Kredit. Debitur mencicil Kredit tiap bulannya sesuai dengan kesepakatan Perjanjian. Masalah yang dihadapi oleh Debitur adalah sebagian besar Debitur tidak bisa membayar angsuran Kredit tersebut dikarenakan usaha Debitur yang menurun dan adanya keadaan memaksa, sehingga Debitur lalai dalam mencicil Kredit dan terjadi Wanprestasi. Sanksi yang diberikan yaitu berupa denda. Untuk mengatasi hal tersebut maka pihak Perumda BPR Majalengka memberi pemberitahuan terlebih dahulu melalui telepon dan memberikan pernyataan lalai atau surat peringatan, juga adanya upaya penyehatan seperti perubahan jadwal pembayaran, penghapusan bunga, jika upaya tersebut masih tidak diindahkan maka pihak Bank akan menyita jaminan yang sesuai dalam perjanjian Kredit.
\end{abstract}

\section{Kata Kunci : Wanprestasi, Perjanjian Kredit, BPR}

\footnotetext{
${ }^{1}$ Dosen Fakultas Hukum Universitas Majalengka
} 


\section{A. Latar Belakang Masalah}

Dewasa ini peranan bank BPR Majalengka dalam membangun kehidupan ekonomi modern tidak dapat lepas begitu saja dari aspek dan tujuan pemberian kredit sebagai upaya untuk mengangkat aspek pertumbuhan modal dan investasi usaha dikalangan para pengusaha yang berada di Kabupaten Majalengka. Dengan demikian bank menjadi suatu lembaga keuangan yang sangat membantu pertumbuhan ekonomi di masyarakat.

Berdasarkan Undang-Undang Perbankan No 10 Tahun 1998 yang dimaksud dengan bank adalah badan usaha yang menghimpun dana dari masyarakat dalam bentuk kredit dan atau bentuk-bentuk lainnya dalam rangka meningkatkan taraf hidup rakyat banyak. Bank menghimpun dana masyarakat kemudian menyalurkan dana kepada masyarakat dengan tujuan bahwa dengan adanya intermediasi ini, maka bank dapat mendorong peningkatan taraf hidup rakyat banyak. Dengan menyalurkan dana kepada masyarakat yang sedang membutuhkan melalui pemberian kredit, misalnya masyarakat bisnis. $^{2}$

Dengan adanya pemberian kredit dilaksanakan juga pelaksanaan perjanjian kredit pada bank BPR, dengan adanya perjanjian itu antara pihak bank dengan nasabah tidak selalu berjalan mulus, masalah yang sering timbul yaitu lalainya nasabah untuk 2melakukan kewajibannya atau yang biasa disebut wanprestasi.

Wanprestasi adalah suatu keadaan dimana seorang debitur (berutang) tidak memenuhi atau melaksanakan prestasi sebagaimana telah ditetapkan dalam suatu perjanjian. Dalam hal ini wanprestasi (lalai/alpa) dapat timbul karena kesengajaan atau kelalain debitur itu sendiri dan adanya keadaan memaksa (overmacht).

Menurut pasal 1313 KUH Perdata, Perjanjian adalah suatu perbuatan dengan mana satu orang atau lebih mengikatkan dirinya terhadap satu orang lain atau lebih. Dimana suatu perjanjian dikatakan sah apabila ada kata sepakat oleh kedua belah pihak, yang tercantum dalam pasal 1320 angka 1 KUH Perdata, yaitu : sepakat mereka yang mengikatkan dirinya, kecakapan untuk membuat suatu perikatan, suatu hal tertentu, dan suatu sebab yang halal.

Pasal 1 angka 11, Undang-Undang Nomor 10 Tahun 1998 Kredit adalah penyedian uang atau tagihan yang dapat dipersamakan dengan itu, berdasarkan persetujuan atau kesepakatan pinjam-meminjam antar bank dengan pihak lain yang mewajibkan pihak peminjam untuk melunasi utangnya setelah jangka waktu tertentu dengan jumlah bunga imbalan atau pembagian hasil.

Menurut Anwar, Kredit adalah pemberian prestasi (jasa) oleh pihak yang satu ke pihak yang lain dan prestasinya dikembalikan dalam jangka waktu tertentu bersama uang sebagai kontraprestasinya (balas jasa).

Dalam hal ini fasilitas kredit yang tersedia di Perumda BPR Majalengka mempunyai tujuan hukum kemanfaatan yang di implementasikan dalam Teori kesejahteraan sosial, sebagaimana yang dikemukakan oleh Friedlander dalam Suud, "Kesejahteraan sosial merupakan sistem yang terorganisasi dari pelayanan-pelayanan dan lembaga-lembaga sosial, yang dimaksudkan untuk membantu individu-individu dan kelompok-kelompok agar mencapai tingkat hidup dan kesehatan yang memuaskan, dan hubungan-hubungan personal dan sosial yang memberi kesempatan kepada mereka untuk

${ }^{2}$ Ismail, MBA, Manajemen Perbankan, Prenadamedia, Jakarta, 2018, hlm.3 
memperkembangkan seluruh kemampuannya dan untuk meningkatkan kesejahteraannya sesuai dengan kebutuhan-kebutuhan keluarga dan masyarakatnya". Jadi dengan adanya fasilitas kredit yang tersedia di Perumda BPR Majalengka, masyarakat yang membutuhkan dana untuk modal usahanya bisa mengajukan kredit, untuk memajukan usahanya dan mencitakan kesejahteraan.

Seorang nasabah debitur yang memperoleh pinjaman kredit dari Perumda BPR Majalengka pada hakekatnya bukan saja bertanggung jawab terhadap Bank sebagai pemberi kredit, tetapi juga memiliki tanggung jawab moral terhadap nasabah penyimpan dana. Penggunaan dana secara benar dan tepat dalam bentuk yang produktif memiliki peran dan memberikan andil dalam pembangunan sektor ekonomi dapat meningkatkan taraf hidup rakyat. Kegagalan pengelolaan dana pinjaman kredit secara langsung dapat merugikan Bank yang bersangkutan dan secara tidak langsung dapat pula merugikan kepentingan nasabah penyimpan.

Pada umumnya perjanjian kredit yang dibuat antara kreditur baik berupa lembaga keuangan bank maupun lembaga keuangan lainnya dan debitur dituangkan dalam perjanjian bentuk tertulis yang sudah dibakukan. Perjanjian semacam ini disebut klausula baku. ${ }^{3}$ Pentingnya jaminan dalam perjanjian kredit Bank adalah sebagai salah satu sarana perlindungan hukum bagi keamanan Bank dalam mengatasi risiko, yaitu agar terdapat suatu kepastian bahwa nasabah debitur akan melunasi pinjamannya. Dalam penjelasan Pasal 8 Undang-Undang Nomor 10 Tahun 1998tentangPerbankan disebutkan bahwa pemberian kredit dalam arti keyakinan atas kemampuan dan kesanggupan nasabah debitur untuk melunasi kewajibannya dengan yang diperjanjikan merupakan faktor penting yang harus diperhatikan oleh Bank. Untuk memperoleh keyakinan tersebut Bank melakukan penilaian atas jaminan atau sebelum memberikan kredit kepada nasabah debitur dengan memperhatikan prinsip kehati-hatian.

\section{B. Rumusan Masalah}

Berdasarkan latar belakang penelitian di atas maka terdapat beberapa permasalahan yaitu sebagai berikut :

1. Bagaimana pelaksanaan Perjanjian kredit antara Perumda BPR Majalengka dengan Debitur?

2. Bagaimana Akibat Hukum yang dilakukan apabila terjadi Wanprestasi?

\section{Tujuan Penelitian}

Adapun tujuan dari penelitian ini :

1. Mengkaji Pelaksanaan Perjanjian kredit Perumda BPR Majalengka dengan Debitur.

2. Mengkaji Akibat Hukum yang ditimbulkan dengan adanya Wanprestasi terhadap perjanjian kredit antara Perumda BPR Majalengka dengan Debitur.

\footnotetext{
${ }^{3}$ Hastuty KL., Jurnal Hukum Responsif, (Cirebon, fakultas hukum unswagati 2011) hlm. 61.
} 


\section{Kerangka Penelitian}

Dewasa ini peranan bank BPR Majalengka dalam membangun kehidupan ekonomi modern tidak dapat lepas begitu saja dari aspek dan tujuan pemberian kredit sebagai upaya untuk mengangkat aspek pertumbuhan modal dan investasi usaha dikalangan para pengusaha yang berada di Kabupaten Majalengka. Dengan demikian bank menjadi suatu lembaga keuangan yang sangat membantu pertumbuhan ekonomi di masyarakat.

Berdasarkan Undang-Undang Perbankan No 10 Tahun 1998 yang dimaksud dengan bank adalah badan usaha yang menghimpun dana dari masyarakat dalam bentuk kredit dan atau bentuk-bentuk lainnya dalam rangka meningkatkan taraf hidup rakyat banyak. Bank menghimpun dana masyarakat kemudian menyalurkan dana kepada masyarakat dengan tujuan bahwa dengan adanya intermediasi ini, maka bank dapat mendorong peningkatan taraf hidup rakyat banyak. Dengan menyalurkan dana kepada masyarakat yang sedang membutuhkan melalui pemberian kredit, misalnya masyarakat

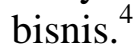

Dengan adanya pemberian kredit dilaksanakan juga pelaksanaan perjanjian kredit pada bank BPR, dengan adanya perjanjian itu antara pihak bank dengan nasabah tidak selalu berjalan mulus, masalah yang sering timbul yaitu lalainya nasabah untuk melakukan kewajibannya atau yang biasa disebut wanprestasi.

Wanprestasi adalah suatu keadaan dimana seorang debitur (berutang) tidak memenuhi atau melaksanakan prestasi sebagaimana telah ditetapkan dalam suatu perjanjian. Dalam hal ini wanprestasi (lalai/alpa) dapat timbul karena kesengajaan atau kelalain debitur itu sendiri dan adanya keadaan memaksa (overmacht).

Menurut pasal 1313 KUH Perdata, Perjanjian adalah suatu perbuatan dengan mana satu orang atau lebih mengikatkan dirinya terhadap satu orang lain atau lebih. Dimana suatu perjanjian dikatakan sah apabila ada kata sepakat oleh kedua belah pihak, yang tercantum dalam pasal 1320 angka $1 \mathrm{KUH}$ Perdata, yaitu : sepakat mereka yang mengikatkan dirinya, kecakapan untuk membuat suatu perikatan, suatu hal tertentu, dan suatu sebab yang halal.

Pasal 1 angka 11, Undang-Undang Nomor 10 Tahun 1998 Kredit adalah penyedian uang atau tagihan yang dapat dipersamakan dengan itu, berdasarkan persetujuan atau kesepakatan pinjam-meminjam antar bank dengan pihak lain yang mewajibkan pihak peminjam untuk melunasi utangnya setelah jangka waktu tertentu dengan jumlah bunga imbalan atau pembagian hasil.

Menurut Anwar, Kredit adalah pemberian prestasi (jasa) oleh pihak yang satu ke pihak yang lain dan prestasinya dikembalikan dalam jangka waktu tertentu bersama uang sebagai kontraprestasinya (balas jasa).

Dalam hal ini fasilitas kredit yang tersedia di Perumda BPR Majalengka mempunyai tujuan hukum kemanfaatan yang di implementasikan dalam Teori kesejahteraan sosial, sebagaimana yang dikemukakan oleh Friedlander dalam Suud, "Kesejahteraan sosial merupakan sistem yang terorganisasi dari pelayanan-pelayanan dan lembaga-lembaga sosial, yang dimaksudkan untuk membantu individu-individu dan kelompok-kelompok agar mencapai tingkat hidup dan kesehatan yang memuaskan, dan hubungan-hubungan personal dan sosial yang memberi kesempatan kepada mereka untuk

${ }^{4}$ Ismail, MBA, Manajemen Perbankan, Prenadamedia, Jakarta, 2018, hlm.3 
memperkembangkan seluruh kemampuannya dan untuk meningkatkan kesejahteraannya sesuai dengan kebutuhan-kebutuhan keluarga dan masyarakatnya". Jadi dengan adanya fasilitas kredit yang tersedia di Perumda BPR Majalengka, masyarakat yang membutuhkan dana untuk modal usahanya bisa mengajukan kredit, untuk memajukan usahanya dan mencitakan kesejahteraan.

Seorang nasabah debitur yang memperoleh pinjaman kredit dari Perumda BPR Majalengka pada hakekatnya bukan saja bertanggung jawab terhadap Bank sebagai pemberi kredit, tetapi juga memiliki tanggung jawab moral terhadap nasabah penyimpan dana. Penggunaan dana secara benar dan tepat dalam bentuk yang produktif memiliki peran dan memberikan andil dalam pembangunan sektor ekonomi dapat meningkatkan taraf hidup rakyat. Kegagalan pengelolaan dana pinjaman kredit secara langsung dapat merugikan Bank yang bersangkutan dan secara tidak langsung dapat pula merugikan kepentingan nasabah penyimpan.

Pada umumnya perjanjian kredit yang dibuat antara kreditur baik berupa lembaga keuangan bank maupun lembaga keuangan lainnya dan debitur dituangkan dalam perjanjian bentuk tertulis yang sudah dibakukan. Perjanjian semacam ini disebut klausula baku. ${ }^{5}$ Pentingnya jaminan dalam perjanjian kredit Bank adalah sebagai salah satu sarana perlindungan hukum bagi keamanan Bank dalam mengatasi risiko, yaitu agar terdapat suatu kepastian bahwa nasabah debitur akan melunasi pinjamannya. Dalam penjelasan Pasal 8 Undang-Undang Nomor 10 Tahun 1998 tentang Perbankan disebutkan bahwa pemberian kredit dalam arti keyakinan atas kemampuan dan kesanggupan nasabah debitur untuk melunasi kewajibannya dengan yang diperjanjikan merupakan faktor penting yang harus diperhatikan oleh Bank. Untuk memperoleh keyakinan tersebut Bank melakukan penilaian atas jaminan atau sebelum memberikan kredit kepada nasabah debitur dengan memperhatikan prinsip kehati-hatian.

\section{Wanprestasi}

Wanprestasi ataupun yang disebut juga dengan istilah breach of contract adalah tidak dilaksanakannya prestasi atau kewajiban sebagaimana mestinya yang dibebankan oleh perjanjian terhadap pihak-pihak tertentu.Wanprestasi sering diterjemahkan dengan ingkar janji atau cidera janji.Perkataan wanprestasi berasal dari bahasa Belanda yaitu wanprestatie. ${ }^{6}$

Mariam Darus menyebutkan wujud dari tidak memenuhi perikatan (wanprestasi) terbagi tiga yaitu : ${ }^{7}$

1) debitur tidak memenuhi perikatan

2) debitur terlambat memenuhi perikatan

3) debitur keliru atau tidak pantas memenuhi perikatan

Abdulkadir Muhammad sama halnya dengan Mariam Darus, menyatakan adanya tiga keadaan wanprestasi yaitu :

1) debitur tidak memenuhi prestasi;

2) debitur memenuhi prestasi, tetapi tidak baik atau keliru. Dalam hal ini, debitur yang memenuhi prestasi, tetapi keliru jika ia tidak memperbaiki kekeliruannya, ia dianggap tidak memenuhi prestasi;

\footnotetext{
${ }^{5}$ Hastuty KL., Jurnal Hukum Responsif, (Cirebon, fakultas hukum unswagati 2011) hlm. 61.

${ }^{6}$ Handri Raharjo, Hukum Perjanjian di Indonesia, Pustaka Yustisia, Yogyakarta, 2009, hlm. 79.

${ }^{7}$ Mariam Darus, Kompilasi Hukum Perikatan, Citra Aditya Bakti, 2001, hlm. 23.
} 
3) debitur memenuhi prestasi, tetapi tidak tepat waktunya atau terlambat;

\section{Perjanjian}

Manusia dalam kehidupan sehari-hari selalu dihadapkan pada hubungan hukum yang dalam hal ini perjanjian melibatkan dua pihak atau lebih, yang masing-masing pihak mempunyai kepentingan yang berbeda antara satu dengan yang lainnya.

Istilah perjanjian berasal dari bahasa Belanda yaitu istilah overenkomst, atau contract dalam bahasa Inggris. Untuk itu, banyak ahli hukum yang memahami sama antara kontrak dan perjanjian. Hal itu sesuai dengan judul Buku III titel kedua tentang "Perikatan-perikatan yang Lahir dari Kontrak atau Perjanjian." Berbeda dengan Subekti yang berpendapat bahwa istilah kontrak mempunyai pengertian lebih sempit daripada perjanjian/perikatan yang tertulis. ${ }^{8}$

Dalam KUHPerdata perjanjian merupakan salah satu dari sumber perikatan (verbintenis) sebagaimana tercantum dalam pasal 1233 KUHPerdata, berbunyi :"Perikatan, lahir karena persetujuan atau karena undang-undang."

Dalam Kamus Besar Bahasa Indonesia, perjanjian adalah persetujuan tertulis atau dengan lisan yang dibuat oleh dua belah pihak atau lebih, masing-masing bersepakat akan menaati apa yang tersebut dalam persetujuan itu. ${ }^{9}$ Kamus Hukum menjelaskan bahwa perjanjian adalah persetujuan yang dibuat oleh dua pihak atau lebih, tertulis maupun lisan, masing-masing sepakat menaati isi persetujuan yang telah dibuat bersama. Berdasarkan Pasal 1313 KUHPerdata memberikan rumusan tentang "perjanjian" sebagai berikut :

"Suatu perjanjian adalah suatu perbuatan dengan mana satu orang atau lebih mengikatkan dirinya terhadap satu orang lain atau lebih". ${ }^{10}$

Menurut R. Setiawan, rumusan tersebut selain tidak lengkap, juga sangat luas tidak lengkap karena hanya menyebutkan persetujuan sepihak saja. Sangat luas karena dengan dipergunakannya "perbuatan" tercangkup juga perwakilan sukarela (zaakwaarneming) dan perbuatan melawan hukum (onrechtmatigedaad). ${ }^{11}$ Sehubungan dengan itu, perlu kiranya diadakan perbaikan mengenai definisi tersebut, yaitu :

a) Perbuatan harus diartikan sebagai perbuatan hukum, yaitu perbuatan yang bersetujuan untuk menimbulkan akibat hukum.

b) Menambahkan perkataan "atau saling mengikatkan diri" dalam pasal 1313 KUHPerdata.

\section{Perbankan}

Kata bank berasal dari bahasa Italia banca berarti tempat penukaran uang. Pengertian bank sendiri adalah sebuah lembaga intermedasi yang menjembatani antara pemilik dana berlebih kepada yang memerlukan dana untuk kemudian diolah demi kesejahteraan bersama yang pengambilannya menurut ketentuan yang berlaku.

\footnotetext{
hlm. 84

${ }^{8}$ Soetojo Prawirohamidjojo dan Marthalena Pohan, Hukum Perikatan, Bina Ilmu, Surabaya,1978,

${ }^{9}$ Departemen Pendidikan Nasional, Kamus Besar Ikhtisar Indonesia, Balai Pustaka, Jakarta, 2005,hlm. 258.

${ }^{10}$ Sudarsono, Kamus Hukum, Rineka Cipta, Jakarta, 2007, hlm. 363.

${ }^{11}$ R. Setiawan, Pokok-Pokok Hukum Perikatan, Bina Cipta, Bandung, 1994, hlm. 49.
} 
Sementara itu, Kasmir, mendefinisikan bank sebagai berikut: "Bank adalah perusahaan yang bergerak dalam bidang keuangan, artinya aktivitas perbankan selalu berkaitan dalam bidang keuangan. Dimana kegiatan utamanya adalah menghimpun dana dari masyarakat dan menyalurkannya kembali dana tersebut ke masyarakat serta memberikan jasa bank lainnya".

Sedangkan menurut Undang-Undang Republik Indonesia Nomor 10 tahun 1998 tentang Perbankan: "Bank adalahbadan usaha yang menghimpun dana dari masyarakat dalam bentuk simpanan dan menyalurkannya kepada masyarakat dalam bentuk kredit dan/atau bentuk-bentuk lainnya dalam rangka meningkatkan taraf hidup rakyat banyak".

Dari beberapa pengertian diatas, maka dapat disimpulkan bahwa Bank merupakan badan usaha dalam bidang keuangan yang kegiatan utamanya yaitu menghimpun dana masyarakat (funding), menyalurkannya dalam bentuk kredit (lending), serta memberikan jasa pelayanan kepada masyarakat.

Dalam praktiknya di perbankan Indonesia saat ini, terdapat beberapa jenis perbankan yang diatur dalam undang-undang perbankan. Namun kegiatan utama atau pokok bank sebagai lembaga keuangan yang menghimpun dana dari masyarakat dan menyalurkan dana tidak berbeda satu sama lain.

Adapun jenis perbankanyaitu : Menurut UU Perbankan Nomor 10 Tahun 1998, jenis bank menurut fungsinya adalah sebagai berikut :

1) Bank Umum, yaitu bank yang melaksanakan kegiatan usaha secara konvensional dan/atau berdasarkan prinsip syariah yang dalam kegiatannya memberikan jasa dalam lalu lintas pembayaran.

2) Bank Perkreditan Rakyat, yaitu bank yang melaksanakan kegiatan usaha secara konvensional atau berdasarkan prinsip syariah yang dalam kegiatannya tidak memberikan jasa dalam lalu lintas pembayaran. Artinya, disini kegiatan BPR jauh lebih sempit jika dibandingkan dengan kegiatan bank umum. ${ }^{12}$

Tujuan utama bank adalah untuk pembangunan nasional dalam rangka meningkatkan pemerataan, pertumbuhan ekonomi dan stabilitas nasional ke arah peningkatan kesejahteraan rakyat banyak.

\section{Kredit}

Kredit dalam bahasa latin disebut "credere" yang artinya percaya, maksudnya si pemberi kredit percaya kepada si penerima kredit,bahwa kredit yang disalurkannya pasti akan dikembalikan sesuai dengan perjanjian, sedangkan bagi si penerima kredit berarti menerima kepercayaan, sehingga mempunyai kewajiban untuk membayar kembali pinjaman tersebut sesuai dengan jangka waktunya, oleh karena itu untuk meyakinkan bank bahwa si nasabah benar-benar dapat di percaya, maka sebelum kredit diberikan terlebih dahulu bank mengadakan analisis kredit. Analisis kredit mencangkup latar belakang nasabah atau perusahaan, prospek jaminannya yang diberikan, serta faktor lainnya tujuan analisis ini adalah agar bank yakin bahwa kredit, yang diberikan benar-benar aman. ${ }^{13}$

\footnotetext{
${ }^{12}$ eprints.perbanas.ac.id/teori-perbankan

${ }^{13}$ Kasmir, Dasar-dasar Perbankan, Raja Grapindo Persada, Jakarta, 2002, hlm. 25.
} 
Pengertian kredit menurut Undang-Undang Perbankan Nomor 10 Tahun 1998 Pasal 1 angka 11 adalah penyedian uang atau tagihan yang dapat dipersamakan dengan itu, berdasarkan persetujuan atau kesepakatan pinjam meminjam antara bank dengan pihak lain yang mewajibkan pihak peminjam melunasi utangnya setelah jangka waktu dengan penmberian bunga.

\section{METODE PENELITIAN}

\section{A. Spesifikasi Penelitian}

Penelitian ini ditekankan kepada deskriptif analisis, yaitu mendeskripsikan tentang problem yang ada di perbankan khususnya bank BPR, menyangkut nasabah yang melakukan wanprestasi berdasarkan Undang-Undang No. 10 tahun 1998 tentang Perbankan.

\section{B. Metode Penelitian}

Metode penelitian ini menggunakan metode pendekatan yuridis normatif, yaitu merupakan penelitian kepustakaan yaitu penelitian terhadap data sekunder. ${ }^{14}$ Pendekatan Yuridis yaitu pendekatan terhadap masalah-masalah yang diteliti dengan hubunganhubungan hukum dari masalah tersebut. Pendekatan Normatif yaitu mendekati masalah yang diteliti dengan mendasarkan pada norma yang berlaku.

\section{Tahap penelitian}

Penelitian ini dilakukan dengan dua tahap, yaitu :

a. Penelitian kepustakaan dalam upaya mencari data-data sekunder, yaitu bahan-bahan hukum yang bersifat mengikat.

1) Bahan hukum primer, yaitu undang-undang, peraturan pemerintah.

2) Bahan hukum sekunder, yaitu memberi penjelasan mengenai bahan hukum primer seperti hasil penelitian atau pendapat para ahli.

3) Bahan hukum tersier, yaitu bahan yang memberikan petunjuk atau penjelasan terhadap bahan hukum primer atau sekunder, seperti kamus, ensiklopedia, bahan di luar bidang hukum yang dapat menunjang dan melengkapi data penelitian

b. Penelitian Lapangan

Mencari data primer atau data yang didapatkan langsung dilapangan untuk memperoleh informasi yang dibutuhkan dalam pembuatan skripsi ini. Data yang diperoleh dari lapangan ini untuk mendukung pembahasan yang berkaitan dengan Wanprestasi dalam Perjanjian Kredit antara Nasabah dan Bank BPR.

c. Teknik Pengumpulan data

Teknik pengumpulan data diusahakan mengumpulkan data sebanyak mungkin yang berhubungan dengan masalah yang akan dijadikan bahan penelitian dengan menggunakan cara studi kepustakaan, wawancara dengan pihak-pihak terkait dan observasi.

d. Alat Pengumpulan Data

\footnotetext{
${ }^{14}$ Ronny Hanitijo Soemitro, Metodelogi Penelitian Hukum, Ghalia Indonesia, Jakarta, 1990 hlm.24
} 
Alat pengumpulan data yang digunakan penulis adalah wawancara, yaitu mengadakan tanya jawab untuk mendapatkan data secara langsung yang terkait khususnya Wanprestasi dalam Perjanjian Kredit antara Perumda BPR Majalengka dengan Nasabah.

e. Analisis Data

Analisis data yang dilakukan menggunakan metode kualitatif, yaitu penelitian ini bertitik tolak pada ketentuan hukum yang berlaku yaitu Undang-Undang No. 10 tahun 1998 tentang Perbankan.

f. Lokasi Penelitian

Dalam penulisan ini, penelitian dilakukan dibeberapa tempat diantaranya adalah sebagai berikut :

1. Studi kepustakaan, yaitu di :

1). Perpustakaan Universitas Majalengka

2). Perpustakaan Fakultas Hukum Universitas Majalengka

3). Perpustakaan Pemda Majalengka

2. Observasi

Perusahaan Umum Daerah (Perumda) Bank Perkreditan Rakyat Majalengka, Kabupaten Majalengka. 


\section{PEMBAHASAN HASIL PENELITIAN}

\section{A. Pelaksanaan Perjanjian Kredit antara Perumda BPR Majalengka dengan Debitur}

Dewasa ini keberadaan bank dalam kehidupan masyarakat mempunyai peran yang cukup penting, karena lembaga perbankan khususnya bank umum merupakan intisari dari sistem keuangan setiap negara.Bank merupakan lembaga keungan yang menjadi tempat bagi perusahaan, lembaga pemerintah, swasta maupun perorangan penyimpan dananya melalui kergiatan perkreditan dan berbagai jasa yang diberikan.Bank melayani kebutuhan pembiayaan serta memlancarkan mekanisme sistem pembayaran bagi semua sektor perekonomian.

Dalam hal ini esksistensi bank dirasakan semakin penting ditengah masyarakat, cukup beralasan bila diperhatikan fenomena dalam transaksi bisnis yang dilakukan oleh masyarakat khususnya dikalangan bisnis mengalami banyak perkembangan sesuai dengan perkembangan dunia bisnis dengan berbagai macam sistem yang ditawarkan.

Jadi bank sebagai lembaga keuangan dalam mengelola dana masyarakat dan pemegang saham diharuskan untuk melakukan pengelolaan secara profesional, sebab jika kepercayaan masyarakat kurang terhadap lembaga ini, maka masyarakat sebagai nasabah akan menarik kembali dana yang telah disimpan di bank tersebut, dampak yang lebih lanjut perekonomian masyarakat bisa terganggu.

Fungsi bank yang demikianlah sangat vital, pembentuk undang-undang mencoba merumuskan fungsi bank tersebut dalam pasal tersendiri. Dalam Undang-Undang Perbankan, terdapat dalam Pasal 3 dikemukakan fungsi utama perbankan adalah sebagai pemghimpun dana dan penyalur dana masyrakat, ${ }^{15}$ hal ini membuktikan bahwa kehadiran bank sebagai suatu badan usaha yang tidak semata-mata bertujuan untuk bisnis, melainkan ada misi lain yaitu peningkatan kesejahteraan masyarakat pada umumnya.

Oleh karena itu, posisi bank ditengah-tengah masyarakat memungkinkan bank mengambil peran dalam segala kegiatan ekonomi masyarakat bisnis, dan tidak terkecuali pelaku Usaha Kecil dan Menengah dalam rangka pengembangan bisnisnya, yang senantiasa melibatkan dunia perbankan dalam hal ini transaksi kredit yang dilakukannya.

Mengingat kebijaksanaan umum perkreditan yang ditempuh pemerintah sebagai bagian integral dari kebijaksanaan pembangunan nasional bersifat pragmatis dan senantiasa disesuaikan dengan perkembangan dan masalah pokok yang dihadapi perekonomian nasional, semenjak pemerintah menerapkan progam-program pembangunan yang terencana, perbankan mempunyai peranan aktif melalui penyediaan kredit. Bank Indonesia menyediakan kredit likuiditas dengan suku bunga murah sampai dengan periode 1 Juni 1983, kepada perbankan atau kredit langsung untuk membiayai program pemerintah atau perusahaan-perusahaan tertentu yang dinilai strategis. ${ }^{16}$

Perjanjian kredit yang dilakukan oleh para pihak yaitu bank selaku kreditur dan nasabah selaku debitur dalam hal ini pelaku Usaha Kecil Menengah diatur dengan hukum perjanjian.Ini berarti para pihak dalam hubungan hukum yang dilakukan para pihak

\footnotetext{
${ }^{15}$ Pasal 3 Undang-Undang Nomor 10 Tahun 1998 tentang perubahan atas Undang-Undang Nomor 7 Tahun 1992 tentang Perbankan.

${ }^{16}$ Thomas Suyatno dkk, Dasar-dasar Perkreditan, STIE Perbanas, Jakarta, 2007, hlm. 32.
} 
memiliki hak dan kewajiban yang harus dipenuhi. Adapun hak dan kewajiban yaitu sebagai berikut :

Bank memiliki kewajiban yang meliputi :

1. Menjamin kerahasiaan identitas nasabah beserta dengan dana yang disimpan pada bank, kecuali peraturan perundang-undangan menentukan lain.

2. Menyerahkan dana kepada nasabah sesuai dengan perjanjian yang telah disepakati,

3. Membayar bunga simpanan sesuai dengan perjanjian.

4. Mengganti kedudukan debitur dalam hal nasabah tidak mampu melaksanakan kewajibannya kepada pihak ketiga.

5. Memberikan laporan kepada nasabah terhadap perkembangan simpanan dananya di bank.

6. Mengembalikan agunan dalam hal kredit telah lunas.

Bank juga berhak :

1. Mendapatkan biaya provisi, adiminstrasi untuk survey, materai, biaya notaris untuk pengikatan kredit dan jaminan (jika diikat secara notaris) dan biaya lainnya misalnya biaya asuransi jaminan (jika jaminan diasuransikan) terhadap produk dan layanan jasa yang diberikan kepada nasabah.

2. Menolak pembayaran apabila tidak memenuhi persyaratan yang telah disepakati bersama dan dalam hal pembayaran angsuran jatuh tempo pada hari libur, maka nasabah harus melakukan pembayaran angsuran pada tanggal 1 (satu) hari kerja sebelumnya.

3. Melelang agunan dalam hal nasabah tidak mampu melunasi kredit yang diberikan kepadanya sesuai dengan akad kredit yang telah ditandatangani oleh kedua belah pihak.

4. Pemutusan rekening nasabah (klausul ini cukup banyak ditemui dalam praktik)

5. Mendapatkan buku cek, bilyet giro, buku tabungan, kartu kredit dalam hal terjadi penutupan rekening.

Pelaksanaan perjanjian merupakan salah satu aspek terpenting dalam perjanjian, karena pelaksanaan perjanjian menjadi tujuan orang-orang yang mengadakan perjanjian. Melaksanakan perjanjian pada hakikatnya adalah berbuat sesuatu atau tidak berbuat sesuatu untung kepentingan orang lain, yaitu pihak yang berhak atas pelaksanaan perjanjian tersebut.

Perjanjian kredit adalah perjanjian pokok (prinsipil) yang bersifat rill.Sebagai perjanjian prinsipil, maka dalam hal ini perjanjian jaminan adalah assessor-nya.Arti rill disini ialah bahwa terjadinya perjanjian kredit ditentukan oleh penyerahan uang oleh bank kepada nasabah debitur.

Perumda BPR Majalengka dalam hal proses pemberian kredit mengacu kepada kebijakan yang berlaku baik ketentuan BI maupun Kebijakan Umum Kredit Perumda BPR Majalengka, didasarkan pada asas kredit yang sehat. Maksud dari proses pemberian kredit yang sehat adalah setiap calon nasabah harus melalui suatu proses penilaian yang dilakukan secara objektif dan memberikan keyakinan dari berbagai unsur bahwa nasabah tersebut dapat mengembalikan kredit yang diberikan oleh bank sesuai waktu yang disepakati.

Untuk memenuhi unsur tersebut Perumda BPR Majalengka menggunakan prinsip- 
prinsip 6 C (Character, Capacity, Capital, Condition, Collateral dan Constraint) terhadap debitur yang dibiayai serta tidak lepas dari kesesuaian, yaitu resiko-resiko yang akan timbul, akhlak dan moral nasabah.

Didalam perjanjian telah dikenal syarat Esensialia, syarat Naturalia, syarat Aksidentalia ketiga syarat tersebut harus ada didalam isi perjanjian tersebut harus ada didalam isi pokok suatu perjanjiann, berkenaan dengan ini maka dalam perjanjian kredit menyangkut syarat Esensialia harus mengatur mengenai pasal tentang pengaturan jumlah kredit, pasal yang mengatur jangka waktu kredit, pasal yang mengatur bunga kredit, pasal yang mengatur syarat-syarat penarikan atau pencairan kredit pasal yang mengatur penggunaan kredit, pasal yang mengatur tentang jaminan kredit, pasal yang mengatur kelalaian debitur atau wanprestasi, pasal yang mengatur asuransi barang jaminan, pasal yang mengatur domisili hukum, pasal yang mengatur tempat dan tanggal lahir perjanjian ditandatangani dan tanggal berakhirnya perjanjian.

Berdasarkan hasil penelitian dilihat dari bentuknya, perjanjian kredit Perumda BPR Majalengka menggunakan bentuk perjanjian baku (standard contract). Dalam pelaksanaanya Bank BPR Majalengka sebagai kreditur telah menyediakan terlebih dahulu berupa surat perjanjian kredit tersebut, sedangkan debitur hanya mempelajari dan memahaminya dengan baik. Perjanjian baku (standard contract) ini dimana dalam perjanjian tersebut pihak debitur hanya dalam posisi menerima atau menolak tanpa ada kemungkinan untuk melakukan negosiasi atau tawar menawar, apabila debitur menerimasemua ketentuan dan persyaratan yang ditentukan oleh bank sebagai kreditur, maka ia berkewajiban untuk mendatangani perjanjian kredit tersebut, tetapi jika tidak debitur bisa menolak untuk tidak mendatangani perjanjian kredit tersebut. Tetapi dalam praktiknya pada BPR Majalengka, umumnya pihak debitur jarang menolak akan perjanjian tersebut, dikarenakan kebutuhan kredit yang sudah tidak dipungkiri dikalangan masyarakat. Bank punya alasan menentukan perjanjian baku ini karena dengan adanya perjanjian baku ini, bank bisa mempunyai kebebasan untuk menentukan klausula-klasula yang ditetapkan. Hal ini cukup beralasan mengingat ada beberapa alasan bagi bank, bahwa perjanjian kredit memiliki fungsi permanen yaitu :

1. Perjanjian kredit berfungsi sebagai perjanjian pokok, artinya perjanjian kredit merupakan sesuatu yang menentukan batal atau tidaknya perjanjian lain yang mengikutinya, misalnya perjanjian pengikatan jaminan;

2. Perjanjian kredit berfungsi sebagai alat bukti tentang batasan-batasan hak dan kewajiban diantara kreditur dan debitur;

3. Perjanjian kredit berfungsi sebagai alat untuk melakukan monitoring kredit.

Perumda BPR Majalengka dalam membuat perjanjian kreditnya dengan berpedoman terhadap ketentuan hukum yang berlaku, sebagaimana berdasarkan Pasal 1338 KUHPerdata yang menyebutkan,

"Semua persetujuan yang dibuat sesuai dengan undang-undang bagi mereka yang membuatnya.Persetujuan itu tidak dapat ditarik kembali selain dengan kesepakatan kedua belah pihak, atau karena alasan-alasan yang ditentukan oleh undang-undang.Persetujuan harus dilaksanakan dengan itikad baik."

Dalam hal ini, Perumda BPR Majalengka menginginkan terjadinya perjanjian kredit ini antara kreditur dan debitur belandaskan undang-undang, dan persetujuan yang tercapai harus dengan kesepakatan kedua belah pihak, dilaksanakan dengan cara itikad baik dalam pengertian suka rela, tidak ada paksaan dari pihak manapun, melainkan dari keinginan 
pihak debitur sendiri.

Perjanjian yang dilakukan Perumda BPR Majalengka dengan Pengusaha Kreditan Pakaian telah memenuhi unsur perjanjian yang sah yaitu berdasarkan Pasal 1320 KUHPerdata atas dasar kesepakatan antara pihak Bank BPR dengan pengusaha kreditan, pengusaha kreditan membutuhkan uang untuk modal meningkatkan usahanya supaya lebih berkembang dan maju. Pihak Perumda BPR Majalengka menyediakan uang sebagai pemberian kredit, sehingga perjanjian tersebut saling menguntungkan kedua belah pihak, walaupun dalam perjanjian tersebut pihak debitur hanya menandatangani surat perjanjian kredit namun tidak ada unsur paksaan untuk terlaksananya perjanjian tersebut.

Menurut Pasal 1320 Kitab Undang-Undang Hukum Perdata yang menjelaskan, "Supaya terjadinya persetujuan yang sah, perlu dipenuhi empat syarat yaitu :

a) Dibuat berdasarkan kesepakatan mereka antara para pihak tanpa ada unsur paksaan, kekhilafan ataupun penipuan;

b) Dibuat oleh mereka yang cakap untuk bertindak dalam hukum;

c) Memiliki objek perjanjian yang jelas;

d) Suatu sebab yang halal.

Apabila suatu perjanjian telah memenuhi syarat yang telah ditentukan dalam Pasal 1320 KUHPerdata sebagai syarat-syarat umum tersebut dan sesuai dengan Pasal 1338 KUHPerdata, maka perjanjian yang telah dibuat berlaku sebagai undang-undang bagi para pihak. Perjanjian tersebut mengikat artinya para pihak wajib melaksanakannya.

Untuk lebih lanjut tentang syarat-syarat sahnya perjanjian yaitu sebagai berikut:

\section{a) Sepakat mereka yang mengikatkan diri}

Awal mula timbulnya suatu perjanjian kredit adalah adanya kesepakatan para pihak yaitu pihak kreditur dan pihak debitur mengenai hal-hal pokok mengenai perjanjian. Jadi disini apa yang dikehendaki kreditur haruslah disanggupi oleh pihak debitur yaitu menerima pembayaran kewajiban pokok dan bunga dengan lancar tepat waktu. Begitupun sebaliknya apa yang dikehendaki oleh pihak debitur haruslah disanggupi oleh pihak kreditur yaitu menerima pinjaman dan menggunakan sesuai dengan tujuannya. Sehingga ada proses kehendak timbal balik antara keduanya. Apabila salah satu pihak tidak menuhi hak dan kewajiban secara sukarela maka salah satu pihak dapat menuntut melalui pengadilan.

\section{b) Kecakapan untuk membuat suatu perjanjian}

Kecakapan para pihak merupakan unsur esensial untuk sahnya suatu perjanjian.Jadi dalam hal ini baik pihak kreditur maupun pihak debitur haruslah orangorang yang dianggap cakap menurut hukum. Jadi disini adanya surat perjanjian kredit yang lahir sebagai realisasi dari adanya persesuian kehendak bahwa para pihak yang terkait dalam masalah perjanjian kredit adalah merupakan orang-orang atau pihak-pihak yang dianggap cakap menurut hukum.

\section{c) Suatu hal tertentu}

Suatu hal tertentu ialah yang menjadi objek daripada perjanjian tersebut artinya bahwa yang dapat menjadi objek perjanjian kredit haruslah tertentu atau dapat ditentukan.

\section{d) Suatu sebab yang halal}

Suatu sebab yang halal disini adalah isi daripada perjanjian tersebut.Jadi dalam suatu perjanjian kredit hal-hal yang termuat dalam isi perjanjian kredit seharusnya 
tidak bertentangan denganketentuan-ketentuan hukum yang berlaku, kesusilaan dan ketertiban umum.

Berdasarkan hasil penelitian, pelaksanaan kredit antara Perumda BPR Majalengka dengan Debitur sudah memenuhi kesepakatan kehendak antara kedua belah pihak, objek perjanjian pun juga jelas dan sebab yang halal disini uang sebagai pinjaman kredit tersebut digunakan untuk modal usaha dan juga unsur kecakapan antara pihak bank dan debitur sudah memenuhi karena mereka sudah cakap atau sudah dewasa untuk melakukan perjanjian.

Pada sisi lain antara pihak bank dengan nasabah terdapat hubungan hukum yaitu hubungan kontraktual dan hubungan non kontraktual. Hubungan kontraktual karena adanya perjanjian atau digunakan pula istilah kontrak, ${ }^{17}$ sebagai dasar hubungan hukum yang dilakukan oleh para pihak yaitu pihak kreditur dan debitur, hal ini dilandasi oleh pemikiran pokok Pasal 1338 KUHPerdata butir (1), bahwa semua perjanjian yang dibuat secara sah berkekuatan sama dengan undang-undang bagi kedua belah pihak.Selain dari hubungan kontraktual terdapat juga 6 (enam) jenis huubungan hukum antara bank dan nasabah yaitu :

a) Hubungan Fidusia;

b) Hubungan Konfidensial;

c) Hubungan Bailor-Bailee;

d) Hubungan Principal-Agent;

e) Hubungan Mortgagor-Mortgagee;

f) Hubungan Trustee-Beneficiary.

Perumda BPR Majalengka menyediakan program bagi masyarakat yang membutuhkan uang untuk mengembangkan usahanya di bidang usaha kecil dan menengah, supaya usahanya berkembang dan maju, dengan adanya program kredit, debitur mengajukan kredit untuk mengembangkan usahanya dana dari Perumda BPR Majalengka sudah jelas dananya sehingga perjanjian bisa dilaksanakan dengan baik.

Debitur dalam membayar kredit tersebut dengan cara menyetorkan uang perbulan kepada pihak Bank Perumda BPR Majalengka tergantung dari pengambilan kredit yang sudah disepakati, semakin besarnya pinjaman, semakin besar pula cicilan kredit perbulannya yang dibebankan kepada debitur.

Perjanjian kredit Perumda BPR Majalengka merupakan suatu proses perjanjian untuk mendapatkan peminjaman uang yang didahului dengan mengadakan pemufakatan diakhiri dengan penyerahan. Terjadinya 2 (dua) momentum hubungan hukum yakni perjanjian kredit lahir pada saat di tandatanganinya Surat Perjanjian Kredit Perumda BPR Majalengka dan kemudian adanya penyerahan uang menyusul ada pernyataan dari pihak Perumda BPR Majalengka.

Dalam proses pencairan kredit Perumda BPR hanya dapat melakukan apabila seluruh syarat-syarat yang ditetapkan dalam persetujuan dan pencairan kredit telah dipenuhi oleh debitur.

\footnotetext{
${ }^{17}$ Munir Fuady, Hukum Perbankan Modern, Citra Aditya Bakti, Bandung, 2003, hlm. 100.
} 


\section{B. Akibat Hukum yang Timbul Pada Saat Terjadinya Wanprestasi}

Perjanjian kredit merupakan ikatan antara bank dengan debitur yang isinya menentukan dan mengatur hak dan kewajiban kedua belah pihak sehubungan dengan pemberian atau pinjaman kredit (pinjaman uang).

Perjanjian kredit biasanya di ikuti dengan perjanjian jaminan sebagai perjanjian ikutan assesoir artinya ada dan berakhirnya perjanjian jaminan tergantung dari perjanjian pokok (perjanjian kredit).

Manakala dikemudian hari persoalan-persoalan hukum yang disebabkan oleh wanprestasi, hal ini telah menyalahi akad kredit yang telah disepakati.Sudikno Mertokusumo menyebutkan perjanjian hubungan hukum antara dua pihak atau lebih berdasarkan kata sepakat untuk menimbulkan akibat hukum. Subekti mengatakan bahwa perjanjian adalah satu peristiwa dimana seorang berjanji kepada orang lain atau dimana dua orang itu saling berjanji untuk melaksanakan untuk sesuatu hal. Dari peristiwa ini timbul suatu hubungan hukum antara dua pihak yang dinamakan perikatan.Perjanjian itu menerbitkan suatu perikatan antara dua orang yang membuatnya.Dalam bentuknya perjanjian itu berupa suatu rangkaian perkataan atau kalimat-kalimat yang mengandung janji janji atau kesanggupan perjanjian.

Dengan demikian hubungan antara perikatan dan perjanjian menerbitkan bahwa perjanjian menerbitkan perikatan.Perjanjian adalah sumber perikatan disamping sumbersumber lainnya.Perjanjian merupakan sumber terpenting dalam melahirkan perikatan karena perikatan paling banyak diterbitkan oleh suatu perjanjian.Perikatan adalah suatu pengertian abstrak sedangkan pejanjian adalah suatu hak yang kongkrit atau suatu peristiwa. $^{18}$

Oleh karena itu bila terjadinya wanprestasi artinya perjanjian yang dibangun tidak lagi merupakan kontruksi hubungan hukum seperti yang diamanatkan oleh ketentuan pasal 1320 KUHPerdata jo Pasal 1338 KUHPerdata. Dan makna Wanprestasi adalah apabila debitur tidak melakukan prestasi atau lalai dalam pembayaran sesuai dengan apa yang tidak ada diperjanjian.

Berdasarkan hasil penelitian, Jumlah nasabah yang wanprestasi di Perumda BPR Majalengka seluruhnya ada 14 orang nasabah debitur. Diketahui bahwa terdapat 9 orang debitur menyatakan faktor penyebab wanprestasi karena usaha debitur yang menurun seperti penjualan yang menurun sedangkan biaya produksi mahal, dan persaingan perdagangan, 5 orang debitur menyatakan faktor penyebab wanprestasi karena keadaan memaksa seperti gagal panen karena cuaca alam, dimana keadaan memaksa yang membuat debitur kesulitan atau diluar kemampuan debitur untuk membayar, sedangkan tidak ada debitur yang wanprestasi karena faktor kesengajaan dalam hal pembayaran. Hal ini dapat diketahui bahwa debitur wanprestasi karena usahanya menurun, gagal panen dan adanya keadaan memaksa.Sanksi yang diberikan berupa denda oleh Perumda BPR Majalengka.Perumda BPR Majalengka memilih melakukan penyelesaian melalui proses pendekatan, bisa berupa penghapusan bunga jadi bayar pinjaman pokoknya saja dan juga pembayaran suka rela (semampunya).

Berdasarkan contoh hasil penelitian yang terdeskripsikan bahwa dengan jelas konteks perjanjian perbankan terjadinya wanprestasi seperti dalam kasus Bapak Saprianto adalah seorang Pengusaha kreditan di bidang pakaian di Leuwimunding dia mengajukan

\footnotetext{
${ }^{18}$ Sutarno, Aspek-aspek hukum perkreditan pada bank, Bina Cipta, Bandung, 2005, hlm. 74.
} 
Kredit di Perumda BPR Majalengka untuk memajukannya usahanya dalam bidang perdagangan pakaian, dan meminjam uang di BPR Majalengka sebesar Rp. 50.000.000 dan jangka waktu selama 3 tahun. Cicilan perbulannya Rp. 2.890 .000 dengan bunga 3\% perbulan dengan jaminan AJB (Akta Jual Beli), dalam pelaksanaan cicilan pertama prestasi sampe cicilan ke28 lancar, tetapi dalam cicilan29-30-31 BapakSapriantolalai dalam mencicil kreditnya, sehingga BapakSaprianto dikatakan Wanprestasi oleh pihak Perumda BPR Majalengka dan dikenakan denda $1 \%$ per hari dari jumlah tunggakan bunga oleh pihak Perumda BPR Majalengka.

Bapak Saprianto mengalami penurunan dalam penjualan pakaiannya, karena para pembeli pakainnya tidak membayar cicilannya, untuk itu pihak Perumda BPR Majalengka melakukan pemberitahuan terlebih dahulu melalui telepon dan berupa surat peringatan atau pernyataan lalai selama 3 kali, tetapi tidak mengindahkan peringatan itu, maka pihak bank memanggil BapakSaprianto sebagai debitur dan menyelesaikannya melalui pendekatan secara musyawarah.

Berdasarkan penelitian, hampir semua debitur yang wanprestasi di Perumda BPR Majalengka, diberikan sanksi berupa denda. Sebagaimana berdasarkan Pasal 6 angka 8 tentang Tabungan, Pencairan dan Pembayaran Angsuran dalam Surat Perjanjian Kredit yang menyebeutkan, "Angka (8) Keterlambatan angsuran tersebut akan dikenakan denda sebesar 1\% perhari maksimal 10\% dari jumlah tunggakan bunga dan harus dibayar seketika dan sekaligus pada waktu penagihan pertama oleh Bank."

Kemudian sebagaimana juga diatur dalam Pasal 15 tentang Cidera Janji/ Wanprestasi dalam isi pasal Surat Perjanjian Kredit yang menyebutkan,

"Peristiwa - peristiwa di bawah ini merupakan cidera janji / wanprestasi Debitur dalam melaksanakan perjanjian ini, didahului atau tanpa didahului dengan surat peringatan khusus/ surat panggilan atau suatu penetapan dari pengadilan melainkan cukup telah terbukti dengan:

1. Debitur tidak membayar angsuran, denda dan biaya lain atas suatu jumlah yang telah jatuh tempo sesuai perjanjian

2. Barang dijual, disewakan, dipindahtangankan, dialihkan atau dijaminkan kepada pihak ketiga

3. Apabila suatu pernyataan, surat keterangan atau dokumen dokumen yang diberikan oleh debitur sehubungan dengan perjanjian ini tidak benar /palsu

4. Kepemilikan jaminan / agunan tersebut diatas nama Debitur atau bukan atas nama Debitur adalah benar milik Debitur, yang diperoleh dengan sah dengan bukti kuitansi dan pernyataan Debitur yang tidak dapat dipisahkan dari perjanjian ini.

5. Terhadap Debitur non lancar dan atau macet, maka Bank berhak:

b. memasang, menuliskan, menempel, kalimat atau kata-kata pengawasan jaminan atau yang dipersamakan dengan itu untuk pengamanan dan pengawasan terhadap jaminan yang diserahkannya untuk agunan yang tidak bergerak

c. meminta penyerahan agunan secara sukarela dari Debitur, terhadap agunan yang bergerak."

Ketentuan hukum ini terlihat jelas ada dasar tatanan nilai untuk membangun kesepakatan agar debitur dan kreditur menyepakati kesepakatan-kesepakatan yang telah diperjanjikan bersama, sehingga dapat diupayakan untuk menghindari terjadinya wanprestasi. 
Dan cara penyelesaian yang terakhir dilakukan oleh Perumda BPR Majalengka adalah dengan cara menyita jaminan debitur sesuai dengan kesepakatan perjanjian untuk dijual bersama-bersama atau dibeli oleh bank sendiri. 


\section{A. Kesimpulan}

1. Pelaksanaan perjanjian kredit Perumda BPR Majalengka dengan Debitur telah sesuai dengan ketentuan hukum yang berlaku. Sudah memenuhi unsur syarat sahnya perjanjian berdasarkan Pasal 1320 KUHPerdata atas dasar kesepakatan antara pihak, kecakapan, suatu hal tertentu, kausa yang halal dan Pasal 1338 KUHPerdata yaitu semua persetujuan yang dibuat sesuai dengan undang-undang berlaku sebagai undangundang bagi mereka yang membuatnya. Persetujuan itu tidak dapat ditarik kembali selain kesepakatan kedua belah pihak, atau karena asalan-alasan yang ditentukan oleh undang-undang. Persetujuan harus dilaksanakan dengan itikad baik. Perumda BPR Majalengka dalam hal proses pemberian kredit mengacu kepada kebijakan yang berlaku baik ketentuan BI maupun Kebijakan Umum Kredit Perumda BPR Majalengka, didasarkan pada asas kredit yang sehat, menggunakan prinsip-prinsip $6 \mathrm{C}$ (Character, Capacity, Capital, Condition, Collateral dan Constraint). Perjanjian kredit antara Perumda BPR Majalengka dengan Debitur dibuat dalam bentuk perjanjian baku, yang demikian pada hakekatnya kehendak yang sebenarnya belum terwujud dalam perjanjian kredit. Perjanjian kredit Perumda BPR Majalengka merupakan suatu proses perjanjian untuk mendapatkan peminjaman uang yang didahului dengan mengadakan pemufakatan diakhiri dengan penyerahan

2. Akibat hukum yang ditimbulkan apabila terjadinya wanprestasi oleh Debitur atau lalainya dalam pembayaran sesuai dengan apa yang telah diperjanjikan. Sanksi yang diberikan yaitu berupa denda, apabila adanya tunggakan pembayaran maka pihak Kreditur akan memberikan pemberitahuan melalui telepon dan surat peringatan/ pernyataan lalai terlebih dahulu. Apabila tidak diindahkan, maka pihak Kreditur akan mengambil langkah upaya penyehatan berupa perubahan jadwal pembayaran, jangka waktu pembayaran diperpanjang dan penghapusan bunga, bayar pinjaman pokoknya saja. Apabila upaya penyehatan tersebut masih tetap tidak disanggupi oleh pihak debitur maka Perumda BPR Majalengka mengambil langkah penyelasaian terakhir seperti menyita jaminan debitur sesuai dengan kesepakatan perjanjian untuk dijual bersama-sama ke pihak lain atau dibeli oleh bank sendiri.

\section{B. Saran}

1. Proses pelaksanaan pemberian kredit telah sesuai dengan ketentuan hukum, untuk itu maka pihak Kreditur agar lebih tegas lagi dalam memberikan sanksi banyak Debitur yang Wanprestasi.

2. Pihak analisis kredit dari Perumda BPR Majalengka agar lebih berhati-hati dalam menilai harga barang-barang jaminan karena harga yang dicantumkan oleh Debitur tidak selalu menunjukan harga sesungguhnya (harga pasar pada saat itu). 


\section{DAFTAR PUSTAKA}

Abdul Kadir Muhammad, Hukum Perikatan, Citra Aditya Bakti, Jakarta, 2000

Ahmadi Miru, Hukum Kontrak dan Perancangan Kontrak, Raja Grafindo, Jakarta, 2010

Djoni S Gajali, RachmadiUsman, HukumPerbankan, SinarGrafika, Jakarta, 2010

Handri Raharjo, Hukum Perjanjian di Indonesia, Pustaka Yustisia, Yogyakarta, 2009

Hamzah Halim, Legal Audit \& Legal Opinion, Kencana, Jakarta, 2015

Hermansyah, Hukum Perbankan Nasional Indonesia, Prenamedia Group, Jakarta, 2005

Ismail, MBA, Manajemen Perbankan, Prenadamedia, Jakarta, 2018

Iswi Hariyani, Restrukturisasi dan Penghapusan Kredit Macet, Elex Media Komputindo, Jakarta, 2010

Johannes Ibrahim, Pengimpasan Pinjaman,(Kompensasi) dan Asas Kebebasan Berkontrak Dalam Perjanjian Kredit, Bandung, CV. Utomo, 2003

J. Satrio, Hukum Perikatan, Perikatan Yang Lahir Dari Perjanjian, Citra Aditya Bakti, Bandung, 1995

KartiniMuljadidanGunawanWijaya, Perikatan Yang LahirdariPerjanjian, RajawaliPers, Jakarta, 2003

Komariah, HukumPerdata, UMM Pers, Malang, 2008

Kasmir, Dasar-dasar Perbankan, Raja Grapindo Persada, Jakarta, 2002

Lukman Santoso, Hukum Perjanjian Kontrak, Panduan Memahami Hukum Perikatan \& Penerapan Surat Perjanjian Kontrak, Cakrawala, Yogyakarta, 2012

M. Bahsan, HukumJaminandanJaminanKreditPerbankan Indonesia, PT Raja GrafindoPersada, Jakarta, 2007.

Munir Fuady, Hukum Kontrak dari sudut pandang hukum bisnis, Citra Aditya Bakti, Bandung, 2007 ,HukumPerbankan Modern, Citra AdityaBakti, Bandung, 2003

Mariam Darus, KUHPerdata Buku III Hukum Perikatan dengan Penjelasan, Alumni, Bandung, 2005 
Mertokusumo, Pengantar Hukum Perdata, Sinar Grafika, Jakarta, 1987

Neng Yani Nurhayani, Hukum Perdata, Pustaka Setia, Bandung, 2015

Rachmadi Usman, Aspek-aspek hukum perbankan di Indonesia, Gramedia Pustaka Utama, Jakarta, 2003

R. Setiawan, Pokok-Pokok Hukum Perikatan, Bina Cipta, Bandung, 1994

R. Subekti, Hukum Perjanjian, Intermasa, Jakarta, 2002

RiduanSyahrani, Seluk-belukdanAsas-asasHukumPerdata, Alumni, Bandung, 2010

Ronny Hanitijo Soemitro, Metodelogi Penelitian Hukum, Ghalia Indonesia, Jakarta, 1985

Richard Eddy, Aspek Legal Properti, Penerbit Andi, Yogyakarta, 2010

Samuel M.P, Penawaran dan Penerimaan dalam Hukum Perjanjian, Grasindo, Jakarta, 2010

Soetojo Prawirohamidjojo dan Marthalena Pohan, Hukum Perikatan, Bina Ilmu, Surabaya, 1978

Sudarsono, Kamus Hukum,Rineka Cipta, Jakarta, 2007

Salim H.S, PerkembanganHukumKontrakInnominaat di Indonesia, SinarGrafika, 2008 2008

Hukum Kontrak, Teori dan Teknik Penyusunan Kontrak, Sinar Grafika, Jakarta,

Sutarno, Aspek-aspek Hukum Perkreditan Pada Bank, BinaCipta, Bandung, 2005

Susanti Adi Nugroho, Hukum Kepailitan di Indonesia, Kencana, Jakarta, 2018

TeguhPudjoMulyono, Aplikasiakuntansimanajemendalampraktekperbankan, BPFE, Yogyakarta, 2002

Thomas Suyatnodkk, Dasar-dasarPerkreditan, STIE Perbanas, Jakarta, 2007

Yan Pramudya Puspa, Kamus Hukum Bahasa Belanda - Indonesia - Inggris, Aneka, Semarang, 1977

Yunirman Rijan dan Ira Koesoemawati, Cara mudah membuat surat perjanjian, Raih Asa Sukses, Jakarta, 2009

Undang-Undang Dasar NegaraRepublikIndonesia Tahun1945 alinea keempat 
Undang-UndangNomor 10 Tahun 1998 tentangperubahanatasUndang-UndangNomor 7 Tahun 1992 tentangPerbankan

Buku ke III KUHPerdata

Undang-Undang Nomor 8 Tahun 1999 tentang Perlindungan Konsumen

Jurnalhukumpropatria, vol. 1, no. 2, September 2007- Februari

Hastuty KL., Jurnal Hukum Responsif, (Cirebon, fakultas hukum unswagati 2011)

Departemen Pendidikan Nasional, Kamus Besar Ikhtisar Indonesia,BalaiPustaka, Jakarta, 2005

www.hukumonline.com/klinik/detail/cl33/wanprestasi-dan-penipuan

http://legalstudies71.blogspot.com/2015/09/hapusnya-suatu-perjanjian-dan-akibat

eprints.perbanas.ac.id/teori-perbankan

yessymsari.wordpress.com/2012/11/29/rahasia-bank 